\title{
A HOUSEHOLD SURVEY ON AWARENESS OF HIV/AIDS AMONG RURAL PEOPLE OF CHANDBELA VDC OF EASTERN NEPAL
}

\author{
Vijay Kumar Khanal, Bijay Thapa , Rajan Bikram Rayamajhi, Puspanjali Adhikari, \\ Shyam Sundar Budhathoki , Anup Ghimire, Suman Bahadur Singh, Paras Kumar Pokharel
}

\begin{abstract}
:
Background: In the past 20 years HIV/AIDS has become an increasing global phenomenon. The rising trend of morbidity and mortality has not only changed the demography but also poses a huge socio-economic burden on well-being of households, communities and country. In Nepal as the epidemic is maturing. However, the epidemic has never been maintained in the general population through heterosexual transmission in Nepal, rather it is driven by the infections among higher risk populations and their sexual partners. Objectives: To assess the knowledge about HIV/AIDS among household level. Material and Methods: A household based survey was conducted in all the nine wards of Chandbela VDC. Interview was conducted using pre-tested semi structured questionnaire which included socio demographic profile and characteristics to assess awareness on HIV/AIDS. The data was analyzed to calculate percentages and proportions. Results: Out of total population (7034), 50.39\% were male and 49.60\% were female. Majority of the males and females were literate i.e. $73.58 \%$ and $51.37 \%$ respectively. Out of 1274 households, 946(74.25\%) households were below poverty line, where $19.34 \%$ of people did agriculture for living and 3.3\% were migrant worker. Most of the people $73.2 \%$ were aware and had heard about HIV/AIDS from various medium like $24.53 \%$ from radio, $15.19 \%$ from friends however, $16.8 \%$ of the people never heard of HIV/AIDS. According to 33\% of people unsafe sexual practice could transmit HIV/AIDS and $28.83 \%$ of people thought avoiding unsafe sexual practice can prevent from acquiring HIV/AIDS. Of the total respondents, $61.6 \%$ of the people believed that even a healthy looking person can have HIV/AIDS. Attitude towards HIV/AIDS patients of majority of population (55.93\%) was to avoid any kind of relation or contact with patient. Conclusion: Although majority of the population were literate, were aware of and had heard about HIV/AIDS, the attitude towards the patient was not positive.
\end{abstract}

Key words: HIV/AIDS, Survey, Awareness, Nepal

\section{Introduction:}

Globally, an estimated 33 million (30-36 million) people were living with human Immunodeficiency virus (HIV) in $2007^{[1]}$. In scaling up response over the past decade, the HIV pandemic remains the most serious infectious disease challenge to global public health ${ }^{[2]}$ consequently, calls have been made for a more pragmatic approach toward containing the disease ${ }^{[3]}$.

In Nepal, the first-ever AIDS case was reported in 1988. Ever since, the nature of the
HIV epidemic in the country has gradually evolved from being a "low-prevalence" to "concentrated" epidemic.[4] Over 80 per cent of the HIV infections are transmitted through heterosexual transmission. People who inject drugs (PWIDs), men who have sex with men (MSM) and female sex workers (FSWs) are the key populations at higher risk spreading this epidemic ${ }^{[5]}$. Male labour migrants (who particularly migrate to high HIV prevalence areas in India, where they often visit FSWs) and clients of FSWs in Nepal are playing the 
role of bridging population groups that transmit infections from the key populations at higher risk to the low-risk general population. The NCASC report also states that 42 percent of all $\mathrm{HIV}$ infections in the country is among Nepali labor migrants to India ${ }^{[4]}$.

It is estimated that about 55,626 people are living with HIV in Nepal in 2010. Majority of infections are occurred among adult (15-49) male (58\%) women of reproductive age group (28\%) populations, while $8 \%$ of infections are occurred among children under 15 years of age ${ }^{[5]}$.HIV is related to behavior that exposes individuals to the virus and increases the risk of infection. Information about HIV and the type and frequency of risk behaviors related to the transmission of HIV is important for identifying and better understanding populations at higher risk for contracting HIV [1]

Thus this study was carried out to assess the level of awareness among the general public about HIV/AIDS, along with their attitude toward PLWHA. Based on the findings, we needed to come up with suitable strategies to correct the misconceptions by Information, Education, and Communication (IEC) activities

\section{Methodology:}

A household based survey was conducted in all the nine wards of Chandbela village of Sunsari district of eastern Nepal. Head of each household of the VDC was interviewed using pre-tested semi structured questionnaire including background characteristics and knowledge regarding Disease transmission and prevention. In the absence or serious illness of the head of household, adult male or female present were interviewed. Three attempts of visits were organised for the house where no one was available in the first visit. Assurance of anonymity and confidentiality of information was maintained. Verbal consent was taken from the respondent. The raw data was edited on the same day of data collection to detect errors and omissions. The data was analyzed to calculate percentages and proportions.

\section{Results:}

Total of 1274 households were surveyed in nine wards of Chandbela village of Sunsari District. Total of 7034 people $(51.76 \%$ male and $48.24 \%$ female) were found to be inhabit the area. Almost $51.37 \%$ were illiterate. About 37.9\% households constituted more than three members in a family. Hindus (90.21\%) predominates over other religions. Around $37.5 \%$ were from tharu ethnicity followed by muslim 9\% and mushahar 5\%. Around $62 \%$ of the families were nuclear and 28.89\% households did not possess any land of their own. $19.34 \%$ of people did agriculture for living and 3.3\% were migrant worker. The most common house $(71 \%)$ was of Kachha type. Only $52 \%$ of families had the nearest health facility in walking distance of less than 30 minutes.

Table:1 Awareness about HIV at household level [ $N=1274]$

\begin{tabular}{|l|c|c|}
\hline Characteristics & Frequency & Percentage \\
\hline $\begin{array}{l}\text { Aware about } \\
\text { theHIV/AIDS }\end{array}$ & 932 & 73.22 \\
\hline $\begin{array}{l}\text { Unaware about } \\
\text { HIV/AIDS }\end{array}$ & 342 & 26.78 \\
\hline
\end{tabular}

About73.22\% of the people had heard about HIV/AIDS while almost $26.78 \%$ had never heard about it.

Table: 2 Sources of Information about Disease [n=932]

\begin{tabular}{|l|c|c|}
\hline Characteristics & Frequency & [\%] \\
\hline Radio & 229 & 24.53 \\
\hline Television & 199 & 21.43 \\
\hline Health Worker & 138 & 14.76 \\
\hline $\begin{array}{l}\text { Community } \\
\text { Gathering }\end{array}$ & 138 & 14.77 \\
\hline
\end{tabular}




\begin{tabular}{|l|c|c|}
\hline Friends/Relatives & 90 & 9.79 \\
\hline School Teacher & 63 & 6.79 \\
\hline Broucher/Pamphlet & 42 & 4.5 \\
\hline Newspaper & 33 & 3.5 \\
\hline
\end{tabular}

\begin{tabular}{|c|c|c|}
\hline $\begin{array}{c}\text { Avoid public } \\
\text { toilets can } \\
\text { prevent AIDS }\end{array}$ & 41 & 4.4 \\
\hline
\end{tabular}

The people had heard about HIV/AIDS from various sources, the chief sources being Radio (24.09\%), TV (21.43\%), Friends/relative (15.39\%) and community gathering (14.77\%)

Table :3 Assessment to HIV/AIDS knowledge [N=932]

\begin{tabular}{|l|c|c|}
\hline $\begin{array}{l}\text { Knowledge } \\
\text { items }\end{array}$ & Number[N] & Percentage[\%] \\
\hline \multicolumn{2}{|c|}{ Mode transmission } \\
\hline Sexual route & 344 & 37 \\
\hline $\begin{array}{l}\text { Blood and } \\
\text { blood } \\
\text { products }\end{array}$ & 186 & 20 \\
\hline $\begin{array}{l}\text { Contaminated } \\
\text { needle and } \\
\text { syringe }\end{array}$ & 158 & 17 \\
\hline $\begin{array}{l}\text { Mother to } \\
\text { child } \\
\text { transmission }\end{array}$ & 121 & 13 \\
\hline \multicolumn{2}{|c|}{ Methods of protection } \\
\hline $\begin{array}{l}\text { Being faithful } \\
\text { to one partner }\end{array}$ & 197 & 21.2 \\
\hline $\begin{array}{l}\text { Use of sterile } \\
\text { needle and } \\
\text { syringe }\end{array}$ & 223 & 24 \\
\hline $\begin{array}{l}\text { Transfusion } \\
\text { of blood } \\
\text { tested for hiv }\end{array}$ & 46 & 20.6 \\
\hline $\begin{array}{l}\text { Use of } \\
\text { condoms }\end{array}$ & 191 & 5 \\
\hline \multicolumn{2}{|c|}{ Myths } \\
\hline $\begin{array}{l}\text { Exchange of } \\
\text { can cause } \\
\text { AIDS }\end{array}$ & 26 & \\
\hline $\begin{array}{l}\text { Using public } \\
\text { toilets can } \\
\text { cause } \\
\text { HIV/AIDS }\end{array}$ & \\
\hline
\end{tabular}

Table: 4 Perception toward Disease who had heard about this [n=932]

\begin{tabular}{|c|c|c|}
\hline $\begin{array}{c}\text { Can healthy } \\
\text { person suffer } \\
\text { from } \\
\text { HIV/AIDS }\end{array}$ & frequency & {$[\%]$} \\
\hline Yes & 574 & 61.6 \\
\hline Don't Know & 196 & 21 \\
\hline NO & 162 & 17.4 \\
\hline
\end{tabular}

To know the perception about the HIV/AIDS among the household level we ask the simple question can healthy person suffer from HIV/AIDS. About sixty two percent of responded yes while eighteen percent still don not know what to say.

Table: 5 Attitude towards the disease person [n=932]

\begin{tabular}{|l|c|c|}
\hline \multicolumn{1}{|c|}{ Characteristics } & frequency & [\%] \\
\hline $\begin{array}{l}\text { Buy vegetables from } \\
\text { people living with } \\
\text { HIV/AIDS } \\
\text { (PLWHA) }\end{array}$ & 521 & 56 \\
\hline $\begin{array}{l}\text { Do not buy } \\
\text { vegetable from } \\
\text { PLWHA }\end{array}$ & 291 & 31 \\
\hline Hesitate to say & 120 & 13 \\
\hline
\end{tabular}

From above table 5 shows that almost fifty six percent of people were positive towards disease person while thirty one percent of respondent responded negatively and still $13 \%$ were hesitate to answer.

\section{Discussion}

This community-based household survey results provide insight into knowledge, attitudes and perceptions towards HIV/ AIDS. Data from our household survey suggest that despite of half of the population of chandbela VDC were illiterate seventy three percent of respondent were aware about the disease as 
compare to Nepal demography health survey which shown that Eighty-six percent of women and 97 percent of men age 15-49 have heard of AIDS.[6] A community based crosssectional study done in Jamnagar Gujrat shown that $60 \%$ of rural heard about HIV/AIDS.[7] also similar findings were reported from study done in our neighboring country India. [8]

Our survey shows that main source of information about the diseases among the respondent was radio(24.53\%) and television(21.43\%) followed by friends and relatives(15.39\%) and health worker(14.74\%) whereas study done by family health international with collaboration with NCASC in 2008 shown that main source of information about disease by friends followed by radio ${ }^{[9]}$. From this study it has shown that overall knowledge regarding disease transmission was low which is slightly higher than study done in Tamil nadu, ${ }^{[10]}$ India where $31 \%$ possessed correct knowledge about its transmission. The poor knowledge of HIV prevention methods among rural inhabitants could be due to poor literacy among these groups and reduced access to HIV/AIDS education material.

Although in our study AIDS awareness was high, there were important misperceptions about risk of HIV by exchange of underwear, sharing public toilet seats and avoid it for prevention. Knowing how HIV is not transmitted is critical for preventing stigma and discrimination against PLWHA ${ }^{[1]}$.

Stigma and discrimination against PLWHA is a key obstacle to HIV/AIDS prevention and care. This study demonstrates that despite of high awareness regarding disease among rural people more than thirty percent of people had unfavorable attitude towards the disease. Study done by Meundi et al ${ }^{[12]}$ also shows the similar finding.

\section{Conclusion:}

In summary, the present study demonstrates relatively good knowledge among rural people of chandbela VDC regarding HIV/AIDS. Nevertheless, there is a more need for HIV/AIDS prevention campaigns targeted toward young men in Nepal to focus on public education, promotion of condom use, and risk-reduction behaviors in urban and rural communities. The negative perceptions of the public toward PLWHA warrant urgent and culturally appropriate multidimensional interventions to reduce HIV/AIDS-related stigmatization and discrimination.

\section{Limitations:}

Information on awareness of HIV/AIDS was limited to only an adult member presented in a household. The information of households remaining closed even after three attempts of Visits could not be known.

\section{Acknowledgement}

We would like to thank all the respondents from chandbela VDC who participated in this study and also students from MBBS, BDS, B.SC nursing Batch 2012 B.P.Koirala Institute of Health Sciences, Dharan

\section{References}

1. UNAIDS, Joint United Nations Programme on HIV/AIDS. 2008. [Cited 2014 march 12]

2. World Health Organization (WHO). AIDS epidemic update. 2007.

3. Asante AD. Scaling up HIV prevention: Why routine or mandatory testing is not feasible for SubSaharan Africa. Bull World Health Organ 2007; 85: 644-6.

4. NCASC Nepal 2007 National Estimates of HIV Infections

5. Department of health services Annual Report 2068/69 (2011/2012), Kathmandu, Nepal: Ministry of Health and Population

6. Nepal Demography Health survey 2011. Kathmandu, Nepal: Ministry of Health and Population, New ERA, and ICF International, Calverton, Maryland. 
7. Yadav et al. Awareness of HIV/AIDS among rural youth in India: A community based cross-sectional study. J Infect Dev Ctries 2011; 5(10):711-716.

8. Kishore J, Sharma S, Ranjan R, Ingle GK (2006) Awareness of HIV/AIDS and STD among rural adolescents in Hathras District of Uttarpradesh. Health Popul Perspect Issues 29: 186-196.

9. FHI/NCASC. Integrated Biological and Behavioral Surveillance Survey among Wives of Migrants. Kathmandu: FHI/NCASC; 2008.

10. Pallikadavath S, Sanneh A, McWhirter JM, Stones $\boldsymbol{R} \boldsymbol{W}$. Rural women's knowledge of AIDS in the higher prevalence states of India: reproductive health and sociocultural correlates. Health Promot Int. 2005; 20:249-259.

11. Lentine DA, Hersey JC, Innacchione VG, Laird GH, McClamroch K, Thalji L. HIV-related knowledge and stigma. MMWR Morb Mortal Wkly Rep. 2000; 49:1062-1064.

12. Meundi AD, Amma A, Rao A, Shetty S, Shetty AK (2008) Cross-sectional population-based study of knowledge, attitudes, and practices regarding HIV/AIDS in Dakshina Kannada District of Karnataka, India. J Int Assoc Physicians AIDS Care 7: 27-34.

Correspondence Address: Dr. Vijay Kumar Khanal, School of Public Health and Community Medicine, B. P. Koirala Institute of Health Sciences, Dharan, Nepal. E-mail: vijaykhanal75@gmail.com 